\title{
Sosiodrama pada Pembelajaran IPS sebagai Upaya Peningkatan Kepercayaan Diri Siswa
}

\author{
Oleh Dinar dan Ahmad Juanda: Latifa \\ Mahasiswa Prodi Pendidikan IPS 2010 FIS UNY
}

\section{Pendahuluan}

Sejatinya pendidikan merupakan suatu upaya membangun dan mengembangkan potensi manusia agar memiliki karakter, integritas, dan kompetensi yang bermakna dalam kehidupan. Namun yang terjadi selama ini, pendidikan cenderung menitikberatkan pada penguasaan aspek pengetahuan. Proses pendidikan dan pengajaran mengabaikan pengembangan sikap dan ketrampilan bersosialisasi, dengan menggunakan pendekatan yang mengarah ke indoktrinasi. Hal ini kurang memberi kesempatan secara luas kepada peserta didik untuk menyampaikan ide-ide dalam pengembangan pengalaman dan potensi yang dimilikinya. Akibatnya pembelajaran seperi ini kurang mendukung pembentukan sikap demokratis.

Sikap demokratis dapat dikembangkan dalam diri setiap peserta didik sebagai bagian dari generasi penerus bangsa. Peserta didik harus mampu menyumbangkan aspirasinya untuk kemajuan bangsa dan negara. Dalam hal ini seorang siswa membutuhkan kepercayaan diri yang tinggi, karena dengan kepercayaan diri yang tinggi inilah individu mampu mengembangkan bakat dan minatnya. Sekolah sebagai lembaga pendidikan memiliki tugas membantu siswa untuk melatih serta meningkatkan kepercayaan diri. Salah satu upaya dalam peningkatan kepercayaan diri siswa adalah melalui pembelajaran dengan metode sosiodrama. Metode sosiodrama cocok diterapkan dalam pembelajaran IPS karena sarat akan materi yang berhubungan dengan aspek sosial.

\section{Pengertian Kepercayaan Diri}

Lauster (dalam Heris Hendriana, 2012: 93), menyatakan bahwa kepercayaan diri merupakan suatu sikap atau perasaan yakin atas kemampuan diri sendiri sehingga orang yang bersangkutan tidak terlalu cemas dalam tindakan- 
tindakannya, dapat merasa bebas untuk melakukan hal - hal yang disukainya dan bertanggung jawab atas per-buatannya, hangat dan sopan dalam berinteraksi dengan orang lain, dapat menerima dan menghargai orang lain, memiliki dorongan untuk berprestasi serta dapat mengenal kelebihan dan kekurangannya. Menurut Rakhmat (2000: 23), kepercayaan diri atau keyakinan diri diartikan sebagai suatu kepercayaan terhadap diri sendiri yang dimiliki setiap individu dalam kehidupannya, serta bagaimana individu tersebut memandang dirinya secara utuh dengan mengacu pada konsep diri. Berdasarkan penjelasan tersebut dapat diketahui bahwa kepercayaan diri merupakan suatu keyakianan atas kemampuan diri sendiri, sehingga seseorang yang memiliki kepercayaan diri dapat mengenali kelebihan dan kelemahan pada dirinya.

Menurut Thursan Hakim (2005: 5) ciri individu yang mempunyai rasa percaya diri yang proporsional yakni selalu bersikap tenang dalam mengerjakan sesuatu, mempunyai potensi dan kemampuan yang memadai, mampu menetralisasi ketegangan yang muncul di dalam berbagai situasi, mampu menyesuaikan diri dan berkomunikasi diberbagai situasi, memiliki kondisi mental dan fisik yang cukup menunjang penampilannya, memiliki kecerdasan yang cukup, dan memiliki pengalaman hidup yang menempa mentalnya menjadi kuat dan tahan di dalam menghadapi cobaan hidup.

\section{Proses Pembentukan Kepercayaan Diri}

Kepercayaan diri merupakan modal dasar seorang manusia dalam pencapaian prestasi. Kepercayaan diri pada seseorang menyumbangkan banyak manfaat bagi individu, karena seseorang yang percaya diri mampu membaur dengan orang lain dan berani menunjukkan kemampuannya. Seseorang yang memiliki kepercayaan diri akan memandang keberhasilan atau kegagalan tergantung dari usaha diri sendiri dan tidak mudah menyerah pada keadaan serta tidak mengharapkan bantuan orang lain.

Kepercayaan diri bukan merupakan bakat (bawaan), melainkan kualitas mental. Artinya kepercayaan diri merupakan pencapaian yang dihasilkan dari proses pendidikan atau pember-dayaan. Kepercayaan diri dapat dilatih atau 
dibiasakan. Faktor lingkungan, terutama orang tua dan guru berperan sangat besar. Anak yang penuh percaya diri akan memiliki sifat-sifat antara lain: lebih independen, tidak terlalu tergantung orang, mampu memikul tanggung jawab yang diberikan, bisa menghargai diri dan usahanya sendiri, tidak mudah mengalami rasa frustrasi, mampu menerima tantangan atau tugas baru, memiliki emosi yang lebih hidup tetapi tetap stabil, mudah berkomunikasi dan membantu orang lain. Pada sisi lain, anak yang memiliki kepercayaan diri yang rendah, akan memiliki sifat dan perilaku antara lain: tidak mau mencoba suatu hal yang baru, merasa tidak dicintai dan tidak diinginkan, punya kecenderungan melempar kesalahan pada orang lain, dan mudah tersinggung (Inge Pudjiastuti, 2010: 40) .

Menurut Thursan Hakim (2002: 8) rasa percaya diri tidak muncul begitu saja pada diri seseorang. Terdapat proses tertentu di dalam pribadi seseorang sehingga terjadi pembentukan rasa percaya diri. Terbentuknya rasa percaya diri yang kuat terjadi melalui proses terbentuknya kepribadian yang baik sesuai dengan proses perkembangan yang melahirkan kelebihan-kelebihan tertentu. Pemahaman seseorang terhadap kelebihan-kelebihan yang dimilikinya tersebut akan melahirkan keyakinan kuat untuk bisa berbuat segala sesuatu dengan memanfaatkan kelebihan-kelebihannya. Selain pengalaman di dalam menjalani berbagai aspek kehidupan dengan menggunakan segala kelebihan yang ada pada dirinya, perlu adanya pemahaman dan reaksi positif seseorang terhadap kelemahan- kelemahan yang dimilikinya agar tidak menimbulkan rasa rendah diri atau rasa sulit menyesuaikan diri. Proses ini menjadikan seseorang akan selalu optimis dan percaya diri dalam menjalani hidupnya.

\section{Metode Pembelajaran Sosiodrama}

Metode pembelajaran berarti suatu cara yang dilakukan dalam proses pembelajaran sehingga dapat diperoleh hasil yang optimal. Menurut Slameto (2010: 65), metode mengajar adalah suatu cara atau jalan yang harus dilalui di dalam mengajar. Pada proses pembelajaran untuk menyampaikan materi yang akan diberikan oleh pengajar kepada peserta didik dibutuhkan cara yang tepat agar 
penyampaian materi dapat maksimal. Cara tersebut seringkali disebut dengan metode, tahap atau pendekatan.

Menurut Nana Sudjana (2009: 76) metode pembelajaran adalah cara yang dipergunakan guru dalam mengadakan hubungan dengan siswa pada saat berlangsungnya pengajaran, oleh karena itu peranan metode pembelajaran sebagai alat untuk menciptakan proses mengajar dan belajar. Berdasarkan penjelasan di atas dapat diketahui bahwa metode pembelajaran adalah cara yang digunakan guru untuk berinteraksi atau menyampaikan materi pembelajaran terhadap siswa agar tercapai proses mengajar dan belajar.

Sosiodrama sering dikenal dengan istilah role playing. Sosiodrama berasal dari kata sosio dan drama. Sosio berarti sosial menunjuk pada kegiatan-kegiatan sosial, dan drama berarti mempertunjukkan, mempertontonkan atau memperlihatkan. Metode pembelajaran sosiodrama berarti cara menyajikan bahan pelajaran dengan cara mempertunjukan dan mempertontonkan atau mendramatisasikan cara tingkah laku dalam hubungan sosial (Tukiran Taniredja, 2012: 39). Menurut Sagala (2009: 213) sosiodrama adalah metode mengajar yang mendramatisasikan suatu situasi sosial yang mengandung suatu problem, agar peserta didik dapat memecahkan suatu masalah yang muncul dari suatu situasi sosial. Abu Ahmad \& Widodo Supriyono (2004: 123) menyatakan bahwa teknik sosiodrama adalah suatu cara yang memberikan kesempatan pada murid-murid untuk mendramatisasikan sikap, tingkah laku atau penghayatan seseorang seperti yang dilakukan dalam hubungan sosial sehari-hari di masyarakat.

Herman J. Waluyo (2001: 54) mengatakan bahwa sosiodrama adalah bentuk pendramatisan peristiwa-peristiwa kehidupan sehari-hari yang terjadi dalam masyarakat. Selanjutnya Herman Waluyo menuturkan bahwa simulasi dan role playing dapat diklasifikasikan sebagai sosiodrama. Nana Sudjana (2005: 84-85) menyatakan bahwa metode sosiodrama dan role playing dapat dikatakan sama artinya, dan dalam pemakaiannya sering disilihgantikan. Sosiodrama pada dasarnya mendramatisasikan tingkah laku dalam hubungannya dengan masalah sosial. Berdasarkan penjelasan tersebut dapat diketahui bahwa sosiodrama merupakan suatu cara yang memberikan kesempatan pada murid-murid untuk 
mendramatisasikan sikap, tingkah laku atau penghayatan peristiwa-peristiwa kehidupan sehari-hari yang terjadi dalam masyarakat. Jadi metode sosiodrama berarti cara menyajikan bahan pelajaran dengan cara mempertunjukkan dan mempertontonkan atau mendramatisasikan cara tingkah laku dalam hubungan sosial.

Tujuan penggunaan sosiodrama menurut Abu Ahmad \& Widodo Supriyono (2004: 123) adalah:

1. Menggambarkan bagaimana seseorang atau beberapa orang dalam menghadapi situasi sosial.

2. Bagaimana menggambarkan cara memecahkan suatu masalah sosial.

3. Menumbuhkan dan mengembangkan sikap kritis terhadap tingkah laku yang harus atau jangan sampai diambil dalam situasi sosial tertentu saja.

4. Memberikan pengalaman atau penghayatan situasi tertentu.

5. Memberikan kesempatan untuk meninjau situasi sosial dari berbagai sudut pandang.

Berdasarkan penjelasan dari Abu Ahmad \& Widodo Supriyono di atas dapat disimpulkan bahwa pembelajaran dengan mengunakan metode sosiodrama memiliki tujuan dalam merangsang sikap kritis siswa dalam menanggapi situasi sosial, sehingga diharapkan siswa memiliki kesempatan untuk meninjau situasi sosial dari berbagai sudut pandang sebagai upaya mengkaji dan menemukan cara pemecahan suatu masalah sosial. Dengan cara tersebut dapat memunculkan kepercayaan diri siswa melalui penerapan pembelajaran sosiodrama.

Cara pembelajaran sosiodrama dapat dilakukan melalui beberapa langkah. Nana Sudjana (2005: 85) menjelaskan petunjuk sosiodrama, diantaranya:

1. Menetapkan dahulu masalah-masalah sosial yang menarik perhatian siswa untuk dibahas.

2. Menceritakan kepada kelas mengenai isi dari masalah-masalah dalam konteks cerita tersebut.

3. Menetapkan siswa yang dapat atau yang bersedia untuk memainkan perannya di depan kelas. 
4. Menjelaskan kepada pendengar mengenai peranan mereka pada waktu sosiodrama sedang berlangsung.

5. Memberi kesempatan kepada para pelaku untuk berunding beberapa menit sebelum mereka memainkan peran.

6. Mengakhiri sosiodrama pada waktu situasi pembicaraan mencapai ketegangan.

7. Akhiri sosiodrama dengan diskusi kelas untuk bersama-sama memecahkan masalah persoalan yang ada pada sosiodrama tersebut.

8. Menilai hasil sosiodrama tersebut sebagai bahan pertimbangan lebih lanjut.

\section{Cara Peningkatan Kepercayaan Diri Siswa Melalui Pembelajaran IPS dengan Metode Sosiodrama}

Ilmu Pengetahuan Sosial atau biasa disingkat IPS merupakan suatu mata pelajaran integrasi dari mata pelajaran Sejarah, Geografi, dan Ekonomi serta mata pelajaran ilmu sosial lainnya (Sapriya, 2011: 7). Menurut Supardi (2011: 186-187) tujuan utama pembelajaran IPS antara lain agar siswa:

1. Menjadi warga negara yang baik melalui ilmu pengetahuan yang diperoleh.

2. Memiliki kemampuan berpikir kritis dan inkuiri sehingga dapat menganalisis dan berpartisipasi dalam memecahkan masalah-masalah sosial.

3. Belajar mandiri melalui program-program pembelajaran yang lebih kreatif inovatif.

4. Mengembangkan kecerdasan, kebiasaan dan keterampilan sosial.

5. Melatih siswa untuk menghayati nilai-nilai hidup yang baik dan terpuji termasuk moral, kejujuran, keadilan, dan lain-lain sehingga memiliki akhlak mulia.

6. Mengembangkan kesadaran dan kepedulian sosial terhadap masyarakat dan lingkungan. 
Berdasarkan tujuan IPS tersebut, metode sosiodrama tepat digunakan dalam pembelajaran IPS. Metode sosiodrama memberikan suasana proses belajar mengajar yang lebih interaktif, tidak monoton, memberikan keleluasaan berfikir pada siswa serta siswa terlibat langsung dalam proses belajar mengajar. Hal tersebut mampu merangsang keberanian siswa untuk aktif berbicara dan tampil di depan kelas, selain itu siswa akan diajak berdiskusi sehingga mampu mengembangkan kemampuan berpikir kritis untuk memecahkan masalah-masalah sosial di masyarakat. Rasa percaya diri akan tumbuh ketika seseorang menghadapi masalah tersebut dan berusaha untuk mengatasinya, bukan menghindarinya. Untuk itu pembelajaran dengan mengunakan metode yang menuntut keaktifan siswa ini dapat meningkatkan kepercayaan diri pada siswa.

Cara pelaksanaan peningkatan kepercayaan diri siswa dengan metode sosiodrama dapat diselenggarakan melalui pembelajaran IPS. Tujuan penggunaan metode pembelajaran sosiodrama dalam pembelajaran IPS adalah untuk meningkatkan kepercayaan diri siswa sehingga siswa dapat lebih aktif dalam pembelajaran di kelas dan tidak enggan untuk menyampaikan pendapat maupun bertanya. Berdasarkan penelitian yang dilakukan oleh penulis penerapan metode sosiodrama dalam pembelajaran IPS dapat meningkatkan kepercayaan diri pada siswa. Berikut akan dijelaskan langkah pembelajaran IPS mengunakan metode sosiodrama dalam materi mengidentifikasi tindakan ekonomi berdasarkan motif dan prinsip ekonomi dalam berbagai kegiatan sehari-hari KD 3.2.

1. Guru membuka proses pembelajaran dengan salam, kemudian dilanjutkan dengan presensi,

2. Guru memberikan bahan materi kepada siswa, selanjutnya guru menjelaskan metode pembelajaran sosiodrama dengan materi mengidentifikasi tindakan ekonomi berdasarkan motif dan prinsip ekonomi dalam berbagai kegiatan sehari-hari.

3. Guru menetapkan masalah-masalah sosial yang menarik perhatian siswa untuk dibahas. Dalam lingkup materi ini siswa dapat mengidentifikasi masalah sosial tentang berbagai alasan yang timbul dalam pengunaan sumber daya. 
4. Guru menceritakan kepada siswa mengenai isi dari masalah-masalah dalam konteks materi tersebut. Dalam materi ini guru menjelaskan macam motif ekonomi.

5. Guru menetapkan siswa yang akan bermain peran di depan kelas. Guru dapat menunjuk secara langsung atau menawarkan kepada siswa yang bersedia untuk memainkan perannya di depan kelas.

6. Guru memberi kesempatan kepada para pemain untuk berunding beberapa menit sebelum mereka memainkan peran. Sementara itu juga guru menjelaskan kepada pendengar mengenai peranan mereka pada waktu sosiodrama sedang berlangsung

7. Guru mendampingi siswa dalam pembelajaran dengan metode sosiodrama yang tengah berlangsung.

8. Guru mengakhiri sosiodrama dengan diskusi kelas untuk bersama-sama memecahkan masalah persoalan yang ada pada sosiodrama tersebut. Siswa diharapkan dapat mengelompokan suatu perilaku individu atau kelompok dalam pengunaan sumber daya sesuai dengan motif ekonomi.

9. Guru menilai hasil sosiodrama tersebut sebagai bahan pertimbangan lebih lanjut.

Peningkatan keaktifan siswa dalam pembelajaran dengan metode sosiodrama berdampak pada peningkatan kepercayaan diri siswa, hal tersebut terlihat dari perubahan sikap siswa dalam mengikuti pembelajaran IPS, yakni:

1. Antusiasme siswa untuk tampil di depan kelas meningkat.

2. Siswa tidak ragu dalam mengemukakan pendapatnya saat proses belajar mengajar berlangsung

3. Siswa tidak merasa enggan untuk bertanya

4. Siswa lebih mudah menyesuaikan diri dan berkomunikasi, hal ini dapat terlihat dari setiap siswa yang mampu berperan dalam dramatisasi suatu situasi sosial, mendiskusikanya bersama di dalam kelas

5. Mempunyai pengendalian diri yang baik, hal ini ditunjukkan dengan sikap siswa yang lebih tenang saat mengikuti proses belajar mengajar. 


\section{Penutup}

Kepercayaan diri pada seseorang menyumbangkan banyak manfaat bagi individu, karena seseorang yang percaya diri mampu membaur dengan orang lain dan berani menunjukkan kemampuannya. Sekolah sebagai lembaga pendidikan memiliki tugas membantu siswa untuk melatih serta meningkatkan kepercayaan diri. Salah satu upaya dalam peningkatan kepercayaan diri siswa adalah pembelajaran dengan metode sosiodrama. Sosiodrama dapat diaplikasikan dalam pembelajaran IPS yang sarat akan materi sosial.

Berdasarkan hasil penelitian yang telah dilakukan oleh penulis metode sosiodrama tepat digunakan dalam peningkatan kepercayaan diri pada siswa. Metode ini mampu menumbuhkan keberanian siswa untuk berekpresi, lebih membaur dengan siswa lain, dan keberanian dalam menunjukkan kemampuan dirinya. Metode sosiodrama melalui pembelajaran IPS dapat mendramatisir peristiwa-peristiwa kehidupan sehari-hari yang terjadi dalam masyarakat. Sehingga dengan pembelajaran yang menuntut siswa untuk aktif berbicara dan tampil di depan kelas dapat melatih kepercayaan diri pada siswa.

Metode pembelajaran sosiodrama mampu meningkatkan kepercayaan diri pada siswa dalam pelajaran IPS, maka dapat dikemukakan saran sebagai berikut:

1. Metode pembelajaran sosiodrama sebaiknya digunakan oleh guru sebagai variasi dalam pembelajaran IPS, di mana banyak materi IPS yang dapat disajikan dengan sosiodrama agar dapat meningkatkan kepercayaan diri pada siswa dengan selalu dibiasakan untuk tampil di depankelas, serta berani dalam menyampaikan aspirasinya.

2. Guru memberikan motivasi kepada siswa agar siswa lebih aktif dalam pembelajaran, memberikan kesempatan kepada siswa untuk bertanya. Agar siswa berani untuk tampil di depan kelas ataupun berani menyampaikan aspirasinya, guru dapat memancingnya dengan memberi apresiasi berupa point keaktifan bagi siswa. Dengan tampil satu kali di depan kelas akan membuat siswa ingin tampil lagi, dengan demikian siswa akan semakin percaya diri. 


\section{Daftar Pustaka}

Abu Ahmad \& Widodo Supriyono. 2004. Psikologi Belajar. Jakarta: Rineka Cipta.

Heris, Hendriana. 2012. Pembelajaran Matematika Humanis dengan Metaphorical Thinking untuk Meningkatkan Kepercayaan Diri Siswa. Jurnal. Jurnal Ilmiah, Vol 1, No.1. Program Studi Matematika STKIP Siliwangi Bandung.

Herman J. Waluyo. 2001. Drama Teori dan Pengajarannya. Yogyakarta: Hanindita GrahaWidya.

Inge Pudjiastuti. 2010. Memperkuat Kepercayaan Diri Anak melalui Percakapan Referensial. Jurnal Pendidikan. No 15.

Rakhmat, J. 2000. Psikologi Agama. Jakarta. Raja Grafindo Persada.

Sapriya. 2011. Pendidikan IPS. Bandung: PT Remaja Rosdakarya.

Slameto. 2010. Belajar \& Faktor-Faktor yang Mempengaruhinya. Jakarta: Rineka Cipta.

Supardi. 2011. Dasar-Dasar Ilmu Sosial. Yogyakarta: Ombak.

Nana Sudjana. 2005. Penilaian Hasil Proses Belajar Mengajar. Bandung: Remaja Rosdakarya . 2009. Dasar- Dasar Proses Belajar Mengajar. Bandung: Sinar

Baru Algesindo

Thursan Hakim. 2002. Mengatasi Rasa Tidak Percaya Diri. Jakarta: Puspa Swara. 2005. Mengatasi Rasa Tidak Percaya Diri. Jakarta: Puspa Swara.

Tukiran Taniredja. 2012. Model-model Pembelajaran Inovatif. Bandung: Alfabeta 